\title{
Conceptual study of the difference between the money market and the capital market
}

\author{
http://doi.org/10.21272/fmir.4(1).51-59.2020
}

\section{Ildikó Wieland}

Dr., Legal Director of the Hungarian Banking Association, Hungary

\section{Levente Kovács}

Dr., Professor, University of Miskolc, Secretary General of the Hungarian Banking Association, Hungary

Taras Savchenko, ORCID: https://orcid.org/0000-0002-5001-609X

Dr., Professor, Sumy State University, Ukraine

\begin{abstract}
The article is devoted to the research of theoretical principles of development of such components of the financial market as the money market and the capital market, identification of key differences between them on the basis of the analysis of scientific professional literature and key provisions of the legislative framework, substantiation of the general interpretation of their essence that could be used in international practice. The article analyzes the peculiarities of formation and functioning of each type of markets, traditional differences between them, examines international practice and statistics on the use of these terms by economic agents, defines the legal basis for understanding their essence and the legal basis for the delineation of these two types of markets. It is proved that a thorough analysis of the peculiarities of the functioning of individual markets, the frequency and popularity of the use of their definitions in economic practice, the definition of users of these types of markets and their functions, form the prerequisites for clarifying the definitions of the essence of each of these markets, with their further global harmonization. The result of the research is the authors' own interpretations of the concepts of "money market" and "capital market". The money market offers an understanding of the transaction system for the purchase and sale of liquid cash or other short-term financial assets, which typically include short-term financial liabilities (up to one year), the purpose of which is usually to provide financing for current operations, short-term profit or financial risk management in the short-term. The capital market is defined in the article as a system of transactions for the purchase and sale of financial assets, which include securities, derivatives or financial transactions, which usually involve long-term financial liabilities, the purpose of which is to satisfy capital requirements or increase capital.
\end{abstract}

Keywords: money market; capital market; financial market; legal basis; international practice, definitions.

JEL Classification: A11, G15, O16.

This work is licensed under a Creative Commons Attribution 4.0 International License

Cite as: Wieland, I., Kovács, L., Savchenko, T. (2020). The distinctive aspects of financial markets. Financial Markets, Institutions and Risks, 4(1), 51-59. http://doi.org/10.21272/fmir.4(1).51-59.2020.

(C) The Authors, 2020. This article is published with open access at Sumy State University.

\section{Introduction}

The financial market is a platform that brings together the needs of sellers and buyers for the trading of financial instruments, which facilitates one particular form of financing, helping investors and savers find each other. Looking at it in a more complex way we can say that the financial market is the scene of money exchange and the entirety of players (individuals and institutions) playing a role in facilitating money exchange (intermediation), as well as of financial instruments, mechanisms, provisions of law, regulations and customary laws. The primary role of financial intermediation is to convey liquid cash generated in the economy (savings, in a broader sense of the word) and capital to users (Losoncz-Farkas, 2011). Within the financial market it is customary to distinguish between money markets and capital markets. The reason behind the differentiation is the fact that the funding of the economy differs by country / culture, based on local traditions, and while in some places it takes place through the intermediation of commercial banks (typically 
through loans with shorter tenors), in other cases there is direct financing provided via the stock exchanges, using securities (with typically longer tenors).

In specialist literature the most usual division of financial markets entails splitting them into a money market and a capital market. The question is along what criteria the two can and should be divided beyond the usual pattern (time factor), and where such division will have significance afterwards. After answering the questions, we aim to provide a generally accepted single definition that can be consistently applied in practice, in specialist literature and in the legislative process.

\section{Classical motions concerning money and capital markets, distinctive characteristics}

The classical grouping of financial markets:

The five different groupings described below offer the opportunity to get to know markets relatively thoroughly:

Table 1. Types of the financial markets

\begin{tabular}{|c|c|c|}
\hline a) & based on the time factor & money market and capital market \\
\hline b) & based on issuing & open and closed market \\
\hline c) & based on the function of the market & primary and secondary market \\
\hline d) & based on the due date of transactions & spot and forward market \\
\hline e) & based on the nature of the financial instrument & the securities market can be highlighted \\
\hline
\end{tabular}

Source: by authors, using the book of Márton Kerekes et al. (1998).

Table 1: Table made internally using the book of Márton Kerekes et al. (1998) titled 'Financial markets' 'Beyond the above, there are numerous further grouping opportunities, such as the degree of concentration, the level of organisation, the intentions of stakeholders or even their quality.' (Kerekes, 1998 (literal reference, reference to the page is missing).

The crafting of a definition cannot be self-serving or, in a branch of science that's developing fast, superfluous, owing to traditions. Consequently, there is need for a definition that supports the logical structure, development and embeddedness of this branch of science. We look at the definition of 'money market' and 'capital market' from this aspect - definitions created, mainly due to traditions, using the 'time factor'.

In financial literature, the timescale of using funding is widely used as a distinguishing factor. Typically, we can speak of short-term funding, which is up to 1 year; or medium-term (2-5 or 7 years) or long-term (longer than 5 or 7 years) financing. Splitting the financial market in two along a subjectively defined timescale is only justified if we see this timescale as a crucial component. Let's take the classification of commercially traded receivables by maturity: 'The market of short-term debt instruments (i.e. those with a maturity of up to one year) is called money market, while the market of long-term debt instruments and shares is defined as capital market.' (Bodie, 2011, p. 46.) There is a practically identical definition of distribution, as follows: 'Money market covers short-term transactions with durations of a mere few hours to one year... while the capital market focuses on deals with longer maturities.' (Pálinkó-Szabó, 2006, p. 40.) Frederic S. Mishkin defines money market and capital market as follows: 'Money market is a financial market that trades in shortterm debt instruments only (those with maturities of up to 1 year), while capital market is the market that trades in long-term debt and equity instruments (with maturities of longer than 1 year)'. (Mishkin, 2010, p. 43) Distribution along the time factor is widely used in specialist literature (see: Zuchy, 2016; Jaksity, 2004, p.85. and p.206-207.; Bod, 2001, p. 66.; Bailey, 2005, p. 4., Haan-Oosterloo-Schonmaker, 2015, p. 161., Kohn, 2007, p. 242., etc.). They tried to resolve the over-mystification of duration by matching the product type with the time aspect as typical characteristics. However, the half-way, time/product combination principle is not exact enough, and does not offer the possibility of progression. Differentiation by subjective maturity (the magic 1 year) does not offer clear enough distinction in respect of the two markets, as there are/may be short-term products and securities that would be judged more to belong to capital markets, if assessed solely on the nature of the product.

This collision results from the inter-relationship between individual distinction aspects, meaning that some players try and define the concept of capital market on a product basis (securities), while other do the same along the time horizon (short-term); however, existing definitions either do not resolve the contradiction between the two (e.g. short-term securities), or regard them as exceptions to the rule that define the rule. 


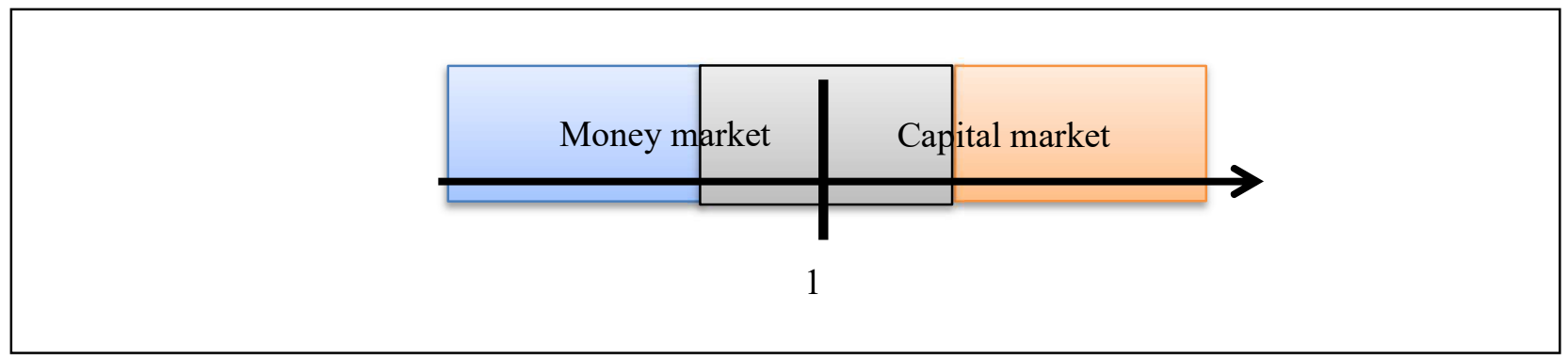

Figure 1. Distinction by maturity

Source: by authors.

Markets are also sometimes distinguished by the type of receivables or the subject of trading; such as e.g. securities market or the market of other financial instruments. 'Liquid cash that can be directly swapped for a product or service; i.e. money itself is the subject of money markets, where demand and supply are not necessary linked through the act of sale/purchase.' (Solt-Kiss, 2007, p. 187) This approach is typically also a subset within the maturity-based approach, as definitions contain the short period remaining until maturity (e.g. Bailey, 2005, p. 4.), or in some places duration is set as 'up to one year' (e.g. Haan-OosterlooSchonmaker, 2015, p.161.)

One solution for going beyond the timescale was to use the types and financing methods of intermediary institutions instead of the timescale as the key traits used in the definition. This approach considers capital markets to be part of money markets. 'The capital market is split into three parts. We distinguish between the market of capital instruments, the market of goods and the market of money and securities...'. In terms of the market of money and securities, the literature quoted uses the following wording: '...from a certain aspect, economic players can be split as savers and those looking for resources/capital. The two are connected by the financial intermediary system, which helps the aforementioned two groups find each other, and the scene of this connection can also be split into two parts: the money market, which, with the co-operation of banks, turns deposits into loans, and the capital market, which has the stock exchange as one of its constituents.' (Cégvezetők, 2005)

Separation by volume and risk-taking might serve as a guideline to investors; however, it does not draw the market demarcation line with due precision. 'Capital markets spread the ownership of capital or certain risky investments between numerous investors, thus allowing players to take on much larger investments and/or risks than what individual owners could tolerate.' (Samuelson-Nordhaus, 2005, p.189) Mishkin says that 'the trading of money market securities is typically conducted in a wider circle that that of long-term securities, and they are also typically more liquid.' (Mishkin, 2010, p. 43) The author notes that the price fluctuation of short-term papers is smaller than that of long-term papers, and therefore it is safer to invest into these. Therefore, companies and financial institutions use this (safe money) market to earn interest on superfluous but only temporarily available resources. At the same time, capital market securities are typically held by financial intermediaries, e.g. insurance companies and pension funds, as they have less uncertainty about the future availability of resources.' (Mishkin, 2010, p. 43)

R.E. Bailey uses a product and time-based approach, and says that the purpose of money markets is to create a trading platform for securities (3 or 6-month government bonds) or facilitate other short-term loans. As a result of such securities being traded on the market, the holder of the money market instrument does not typically have to wait until the end of the contract's full tenor; i.e. execution by the issuer. (R.E. Bailey, 2005, p.4)

There is also a definition, which unites various sets of considerations and says that 'Money market is basically the market of short-term (up to 1 year), liquid, fixed-interest, low-risk, easy-to-trade credit instruments. As such instruments are typically traded in bulk, individual investors may only access them in the form of money market funds. Money markets typically mostly serve the purpose of bridging the time gap between the realisation of the income and expenditure items of companies and the state.' (Gábler)

It is clear that these approaches are rather theoretical (based on customs) and do not look into why it is even necessary to define and separate money and capital markets. There are numerous arguments supporting the notion that we can speak of money market in itself, without content, and if there is a more detailed breakdown required, then, keeping in mind the objective in hand, we can further break it down to individual sets and specific transactions by naming specific products. 
Nevertheless, it is clear that we do use the terms money market and capital market with natural ease in provisions of law and contracts; however, the underlying content is interpreted individually by each player, partly due to the variety of prevailing definitions.

Definitions of the money and capital markets from aspects such as time, liquidity, risk or product characteristics do not offer additional information or investor protection guidelines to investors; however, it must be noted that they may be suitable for differentiating between the banking activities pursued by investors, which may serve as a logical starting point.

Going beyond the time aspect was clearly and transparently summarised by András Vígvári: 'The conventional approach of looking at maturities was the right one right until state regulations clearly distinguished the institutions of indirect and direct financing, and therefore also their markets, and the liquidity of financial markets wasn't overly high.' (Vígvári, 2008, p. 177-178.) In other words, with the development of financial markets, globalisation and the mixing of financial cultures and products it entails the definition based on subjective timescales can no longer be sustained.

\section{The approach used in legislation}

It is interesting to point out that, at present, no definition exists for these markets in financial legislation. When aiming to establish a definition, it must also be clearly seen that these concepts have not been defined in the EU's, Hungary's or the USA's legal systems either. In some cases, the legal approach also shows a certain degree of tautology in this respect when Section 17, Article 4 of the MiFID II EU guideline or Act No. CXX of 2001 on Capital Markets in Hungary defines 'money market instrument' as an instrument that is traded on the money market, without defining the exact nature of such market. In addition, there is also certain degree of contradiction in the sense that the law defines money market instruments as a subset of financial instruments, which, by the way, are traded on the capital market. Nevertheless, it can be assumed that here the legislator wishes to point out the 'non-security' and short-term nature of the product, instead of trying to define a market differentiator trait.

It must be noted that the general contracting terms and conditions of financial institutions also use the concept of money and capital markets as an axiom; i.e. they also use it as a nation with natural ease. However, specialists who draft such general contracting terms and conditions have not attempted the precise description and definition of such markets either.

EU institutions are also happy to use the names of these respective markets without defining their underlying content. Just an example concerning the EU-level regulation of financial services and the challenges it entails: According to the position paper issued by the European Parliament on 19 January 2016 (2015/2106 (INI) on the impacts and the more efficient and effective EU framework of financial regulation on the way leading to capital market union, the capital market union could be an effective solution for creating a single, cross-border capital market. Amongst the underlying reasons it mentions that the capital market of the European Union remains dispersed, and therefore the capital market union (CMU) may offer a valuable framework for providing equal access to SMEs to funding EU-wide, as well as for promoting the creation of innovative platforms for market-based financing. It also notes that CMU creates the opportunity to strengthen the capital markets of EU with a view to boosting their ability to supplement financing by banks. The objective of the capital market union is to deepen and even more tightly integrate the capital markets of EU member states, where the legislator can set the content behind such objective through the definition of EU pillars for individual capital markets.

It is to be noted that the expressions of 'money market' and 'capital market' are used at all levels of the EU legal hierarchy; however, they are notions that remain undefined. The Treaty on the Functioning of the European Union (TFEU) also uses the expressions 'capital market and 'money market', and they also appear in regulations specific to individual sectors.

\section{International financial markets, statistics}

As an additional factor, it must also be reflected that the depth of international financial markets can be defined as the quotient of the financial asset portfolio and GDP. (Losoncz-Farkas, 2011) 
Traditional and local distributions are existing concepts in respect of financial markets. In continental Europe, money market-based forms of financing are more typical and traditional, while the same is true for capital market financing in the US.

The different financial structures prevailing in individual countries determine the typical access path for companies to the various forms of financing. In a different study, it may also be worth looking into how the different forms of financing impact growth in the different economic cycles. However, for us to be able to discuss economic issues in an effective manner, we need to fine-tune notions and definitions, and get them generally accepted.

In boom periods legislative bodies are also more relaxed to see an institution, e.g. an 'investment bank' perform more and more activities and sell more and more products 'alien to the world of the institution in question', as there are also cost efficiency factors at play. At the same time, world crises and major economic declines yet again raise the rightful worry that can be typically linked to such periods, that there is a lack of clarity when it comes to products and, ultimately, activity profiles, and such products and activities are not clearly allocated to specific types of institutions. Consequently, it can be rightfully argued that the notions of 'money market' and 'capital market' should be differentiated. The article is not aiming to return the system to the previous status quo; it merely aims to create clarity and better understanding in the subject.

The notions themselves and the fact of making a distinction between them may also carry statistical relevance, when it comes to, for example, to the balance of payments. Although the international methodological framework is mainly defined by the balance-of-payments/statistics manual, yet, the original separation applied by the financial profession can also come in handy when it comes to real economy and financial deals taking place in the economy.

\section{Legal distinction based on an economic approach}

Going beyond the time aspect, it is now worth looking into the opportunities offered by the new definition criterion, also keeping the legislative framework in mind.

We 'instinctively' identify financial institutions and financial intermediaries with markets, credit institutions with money markets and investment businesses (brokers) with capital markets. (Szász, 1947, p.22-23.)

Financial intermediary institutions collect small-value, temporarily available liquid cash from savers, and use them to satisfy the much higher-value financing needs of economic players. (Erdős-Mérö, 2010, p.19.) Intermediaries perform an efficiency-boosting, quality asset transformation (risk management) and resourcereallocation function between savers and companies to be financed, which gives them an important role on the financial market. (Erdős-Mérö, 2010, p. 20-25.)

The distinction of specific markets has significance for defining the concepts prevailing in financial intermediation, and, within that, for identifying the content of operating licences. The activities pursued by institutions active on the financial market can be distinguished by the form and characteristics of financing offered by them; i.e. in what form they enjoy the 'utilisation' of certain types of savings. Thus, it is not the target audience that determines the market's identity, bit the scope of activity of the institution offering the service. The previous objective of the law, i.e. classical institutional distinction could only be achieved through the precise allocation of activities, meaning that a credit institution can collect deposits or offer a credit facility of cash loan (i.e. perform credit institution or financial activities), while an investment business performs investment services, e.g. is involved in security trading.

At the same time, it is clear to see that no given bank can be present on the market as a money market player and a capital market actor at the same time; i.e. as an entity both offering and using such services. In order to be able to define the market it is necessary to start out from the products and the provision of services, and the operating licence sets the framework for these. When defining markets, looking at the services used by the institution as a starting point may trigger us to draw the wrong conclusions, as banks may, on occasion, acquire the resources required for performing their banking activities from the capital market. Accordingly, the scope of players emerging on the demand side does not offer good guidance for the distinction of the two different markets, as households, the state and representatives of the non-financial sector also emerge on the demand side of individual markets.

Having established the importance of the supply side, it can be suspected that it may guide the process of market definition. However, in terms of the provision of services and the granting of operating licences it is 
also important to stipulate, right from the start, that there are so-called universal 'banks', whose operating licences are not necessarily determined by the company's form of association or name under financial law, or even the possession of licences for activities that are classically linked to the name of such institution. Legal stipulations also increasingly depart from the concept of linking clear-cut definitions of institutions to clearcut definitions of activities, as the development of market requirements and economic rationales (cost efficiency) demand that there is a certain degree of interchangeability between activities and institutions.

It's worth looking into whether the distinction between money market and capital market has significance from an investor and customer protection point of view as well, as in case of a universal bank the client faces a specific institution, where it can benefit from multiple services, meaning that in his/her capacity as a buyer, the client emerges on different markets. It is therefore a rightful requirement from customers to have a clear picture on how they can settle any losses resulting from the services used by him/her or from issues faced by its business partner. To be able to make a decision based on a thorough risk assessment, the customer must also see hardware much the service they are using is 'protected', i.e. whether they can get any 'external' indemnification or damages, should certain events take place. The type of the institution itself does not clearly define the guarantees linked to the deals closed with the institution or the insurance system, as it always depends on the type of the service in hand provided by the institution; i.e. on which market the deal is concluded. We only briefly refer to customer and investor protection aspects because, on the one hand, the identification of the guarantee from the market's aspect does not offer the true picture, as not all services are offered. On the other hand, this aspect is only relevant in relationships between universal banks and nonfinancial institutional investors and customers ${ }^{2}$, e.g. in relationship(s) between natural persons, but not for institutional contracting parties, and therefore its usage for solely market-based distinction would be strongly misleading.

The scope and content of the operating licence can truly show the character of a given market through the services and instruments offered by the institution. Accordingly, the provision of financial services takes place on the money market, or, looking at it the other way, it is on the money market that financial services are being provided and such services are used. According to Act No. CCXXVII of 2013 on Credit Institutions and Financial Enterprises, financial services include the provision of credit and cash loans, financial leasing, deposit collection, the acceptance from the public of other repayable financial instruments, money exchange or the provision of payment services, whose underlying subject is cash or cash-substituting means of payment. This is also significant because there are services, e.g. custody services that can occur in the activity range of both credit institutions and investment businesses; however, their subjects are different (cash vs. financial instrument).

The subject of investment service activities is financial instruments, and therefore such services, such as the taking and execution of orders, portfolio management or investment advice, may only be performed by institutions with a licence to perform investment services. Investment businesses and institutions with a licence to offer investment services provide such services on capital markets. Looking at it the other way: the capital market is the place where the provision of investment services takes place.

In summary, the market turnover that can be established from the above does not serve as a direct starting point or a distinction criterion from a consumer protection aspect, and it does not offer guidance in terms of transparency or profitability, and it's not possible to draw direct conclusions from it regarding risk. It is, however, the place where activities and services detailed in the operating licence are performed/provided, where demand and supply for the subject of the service also occur.

Also, the conception of the Ukraine money market was developed in previous article (Savchenko T.G., Piontkovska Y.O., 2013) on the basis of scientific approaches, author's understanding of the essence and structure of money market and Ukrainian legislation.

\section{The definition of 'money market' and 'capital market'}

In Hungarian and international literature, the definitions of money market and capital market are inconsistent, and are characterised by significant deviations and definition gaps, in the spirit of author's freedom.

\footnotetext{
${ }^{2}$ Customers not excluded from the indemnification scheme of the National Deposit Insurance Fund and the Investor Protection Fund in Hungary
} 
We could not derive a single, consistent definition from provisions of law prevailing in Hungary, in the European Union and in the US. Due to the inability to arrive at a definition using the concept of a market dataset, in specific provisions of law legislators circumpassed the issue by relying on the 'market' components required in that specific piece of legislation to achieve its purpose. However, such components were mostly only mentioned as examples, even though the full list could be replaced by a single, unified definition of terms and concepts.

There can be the following distinction criteria and gaps between markets:

Table 2. Distinction criteria between money and capital markets

\begin{tabular}{|c|c|c|}
\hline & Money market & Capital market \\
\hline Role & $\begin{array}{l}\text { Serves the purpose of compliance with working } \\
\text { capital requirements in the economy, and it has a } \\
\text { role in ensuring sufficient liquidity for banks }\end{array}$ & $\begin{array}{l}\text { It serves an investment purpose with a view to achieving } \\
\text { an increase in capital }\end{array}$ \\
\hline $\begin{array}{l}\text { The content of interest } \\
\text { (rate) }\end{array}$ & $\begin{array}{l}\text { The money market interest rate is determined by the } \\
\text { demand for and supply of money; i.e. it represents } \\
\text { the value of money. } \\
\text { Therefore, in any given country, the short-term } \\
\text { interest rate is the indicator of monetary and banking } \\
\text { conditions. }\end{array}$ & $\begin{array}{l}\text { The operation of the capital market largely depends on } \\
\text { the conditions characteristic of money markets. The } \\
\text { short-term interest rate affects longer-term interest rates } \\
\text { characteristic of capital markets. }\end{array}$ \\
\hline $\begin{array}{ll}\text { Key } \\
\text { players }\end{array}$ & $\begin{array}{l}\text { Central bank, commercial bank, non-financial } \\
\text { institutions }\end{array}$ & $\begin{array}{l}\text { Stock exchange, commercial bank and other financial } \\
\text { institutions (e.g. insurance company and mortgage } \\
\text { bank) }\end{array}$ \\
\hline $\begin{array}{l}\text { Characteristic of the } \\
\text { market }\end{array}$ & Informal & Formal \\
\hline $\begin{array}{l}\text { Typically traded } \\
\text { financial instruments }\end{array}$ & $\begin{array}{l}\text { Draft, cheque, short-term certificates of deposit, } \\
\text { treasury bonds, commercial loans, short-term bonds, } \\
\text { FX derivatives, interest rate swap transactions, } \\
\text { commodity derivatives, loan derivatives) }\end{array}$ & $\begin{array}{l}\text { Shares, bonds (medium or long-term), other long-term } \\
\text { securities }\end{array}$ \\
\hline Liquidity & Typically high & Relatively low \\
\hline Risk & $\begin{array}{l}\text { Lower risk } \\
\text { Investors step on the market with the expectation } \\
\text { that liquidity is available, and they can trade on a } \\
\text { secure market. }\end{array}$ & $\begin{array}{l}\text { Relatively high risk } \\
\text { Objectives include savings and the realisation of } \\
\text { medium and long-term investments. }\end{array}$ \\
\hline Yield & Lower & Relatively high \\
\hline
\end{tabular}

Source: Katsiaryna Marmilava, $2017 .^{3}$

The first reading of economic and legal approaches may suggest the instinctive solution of associating credit institutions with money markets and investment businesses (brokers) with capital markets. However, in respect of the licencing of individual financial activities, we have come to a more sophisticated solution by identifying a clear demarcation line. This approach facilitates a clear definition. As for the future, in view of the above parameters, we can formulate the following definition suggestions:

A. Money market: The money market is a system of transactions closed in respect of liquid cash or other short-term financial assets typically involving short-term financial obligations (of up to one year), where the purpose of the deals is typically to ensure financing for current operations, short-term profit-making or the management of financial risks in the short run.

B. Capital market: A system of transactions closed in respect of financial assets, including, in particular, securities, derivative deals or financial agreements which typically involve long-term financial obligations, which objective is to satisfy capital requirements or boost capital.

\section{Conclusion}

These new definitions, on the one hand, identify the product itself and, as a result, through the product's unique traits, the characteristics of the market (maturity, risk), and, on the other hand, at the same time they also define participants on the supply side. The definition combines previous theories; however, it eases the previous practice of erecting a Chinese wall between the two markets based on, for example, the product's features, uniqueness ( 1 year, risky etc.). Due to the clear-cut nature and simplicity of the definition, which correctly 'grabs the character' of the matter, and combines the various classical notions that exist about

${ }^{3}$ Further references: Oosterloo, (2009) and O’Sullivan (2003). 
Financial Markets, Institutions and Risks, Volume 4, Issue 1, 2020

ISSN (online) - 2521-1242 ISSN (print) - 2521-1250

financial markets without citing categories from corporate law, it can be easily extended if so required by potential changes in law, and therefore they are put forth for general acceptance.

\section{Reference}

1. Bailey, R. E. (2005). The Economics of Financial Markets, Publisher: Cambridge University Press, ISBN: 9780521612807. https://doi.org/10.1017/CBO9780511817458

2. Bod, P. Á. (2001). A pénz világa - a világ pénze (The world of money - money in the world), Publisher: KJK-Kerszöv, ISBN 9632245849

3. Bodie, Z., Merton, R. C., Cleeton, D. L. (2011). A pénzügyek közgazdaságtana (Financial Economics), Publisher: Osiris, ISBN 9789632761824. Available at: https://www.academia.edu/36740595/ Financial_Economics_2Ed_by_Bodie_Merton_and_Cleeton

4. Cégvezetők Kiskönyvtára (Library of managers), 2005/02. Publisher: Hírtőzsde (News exchange), ISSN 2062-459X. Available at: https://cegvezetokklubja.hu/2005/04/

5. Erdős, M., Katalin, M. (2010). Pénzügyi közvetítő intézmények / Bankok és intézményi befektetők (Financial intermediaries / banks and institutional investors), Publisher: Akadémiai, ISBN 9789630589604

6. Gábler Gergely: Pénz és tőkepiacok (Money- and capital markets) Pénzügyi Feladatok Nemzeti Szakképzési és Felnőttképzési Intézet (Institution of Financial Tasks for National Education) SzT- 031-8. Available at: http://193.231.19.17/kozgazdaszforum.ro/admin/upload/775 KF 2017 4. cikk2.pdf

7. Haan, de J., Oosterloo, S., Schonmaker, D. (2015). Financial Markets and Institutions, Publisher: Cambridge University Press, ISBN: 9781107539365

8. Jaksity, G. (2004). A pénz természete (The attribute of money), Publisher: Alinea, ISBN 9638630655. Available at: https://www.academia.edu/6214382/P\%C3\%89CSI TUDOM\%C3\% 81NYEGYETEM K\% C3\%96ZGAZDAS\%C3\%81GTUDOM\%C3\%81NYI KAR GAZD\%C3\%81LKOD\%C3\%81STANI DOK TORI ISKOLA

9. Kerekes Márton et al. (1998). Pénzügyi piacok (Financial markets), Publisher: Saldo, ISBN 9636218668.

10. Losoncz, M., Farkas, P. (2011). Nemzetközi pénzpiacok (International money markets), Publisher: Széchenyi István Egyetem. Available at: http://docplayer.hu/487191-Nemzetkozi-penzpiacok.html

11. Meir Kohn (2007). Bank- és pénzügyek, pénzügyi piacok (Banking and finance, financial markets), Publisher: Osiris, ISBN: 9789633899564.

12. Marmilava, K. (2017). Miskolci Egyetem, University of Miskolc, Ph.D. házi dolgozat, Ph.D. home assignment. Available at: http://studyinhungary.hu/institution/university-of-miskolc-82.html

13. Mishkin, F.S. (1992). The Economics of Money, Banking, and Financial Markets (3rd edition), Publisher: HarperCollins Publisher ISBN 0-673-52141-9. Available at: https://www.com/EconomicsBanking-Financial-Markets-Harpercollins/dp/0673523780

14. Haan J., Oosterloo S., and Schoenmaker, D. (2009). European financial markets and institutions. Cambridge University Press, New York. Available at: https://forfreeshare.weebly.com/uploads/1/2/5/1/ 12515971/european_financial_markets_and_institutions.pdf

15. O’Sullivan, Arthur; Sheffrin, Steven M. (2003). Economics: Principles in Action. Upper Saddle River, NJ: Pearson Prentice Hall. p. 283. Available at: http://www.gbv.de/dms/zbw/640430643.pdf

16. Pálinkó Éva - Szabó Márta (2006). Vállalati pénzügyek, (Corporate finance) Publisher: Typotex. Available at: https://www.typotex.hu/book/396/palinko_eva_szabo_marta_vallalati_penzugyek

17. Samuelson-Nordhaus (2005). Közgazdaságtan (Economics), Publisher: Akadémiai, ISBN 9630582996. Available at: https://akademiai.hu/187/economics_books/economics/kozgazdasagtan_bovitett_ atdolgozott_kiadas

18. Savchenko T.G., Piontkovska Y.O. (2013). Struktura ta instrumenty` groshovo-kredy`tnogo ry`nku (Structure and Instruments of the Money Market), Problemy` i perspekty`vy' rozvy'tku bankivs`koyi 
sy`stemy`Ukrayiny`: Zbirny'k naukovy`x pracz. (Problems and Prospects for Development of the Banking System of Ukraine. Collection of sciences papers). Publisher: UAB NBU, p.169

19. Katalin, S. Gáspár, K. (2007). Pénzügytan II., Pénzügyi piacok, (Finance theory II. Financial markets), Universitas-Györ Kht. Available at: https://www.antikvarium.hu/konyv/dr-solt-katalin-dr-vigvari-andraspenzugytan-i-586294

20. Szász, A. (1947). Banküzemtan, (Commercial Banking) Publisher: TÉBE (Budapest).

21. Vígvári, A. (2008). Pénzügy(rendszer)tan (Finance (taxanomy), Publisher: Akadémiai, ISBN 9789630585958.

22. Zucchy, K. (2016). Financial Markets: Capital Vs. Money Markets. Available at: http://www.investopedia.com/articles/investing/052313/financial-markets-capital-vs-money-markets.asp 